@ERSpublications

Plasma CC16 levels are associated with CC16 gene polymorphisms and inversely with chronic bronchitis http://ow.ly/O8CHk

Hans Petersen ${ }^{1}$, Shuguang Leng ${ }^{1}$, Steven A. Belinsky ${ }^{1}$, Bruce E. Miller ${ }^{2}$, Ruth Tal-Singer ${ }^{2}$, Caroline A. Owen ${ }^{3}$, Bartolome Celli ${ }^{3}$ and Yohannes Tesfaigzi ${ }^{1}$

${ }^{1}$ Lovelace Respiratory Research Institute, Albuquerque, NM, USA. ${ }^{2}$ Research and Development, GSK, King of Prussia, PA, USA. ${ }^{3}$ Pulmonary Division, Brigham and Women's Hospital, Harvard Medical School, Boston, MA, USA.

Correspondence: Yohannes Tesfaigzi, COPD Program, Lovelace Respiratory Research Institute, 9495 Ridgecrest Dr., SE, Albuquerque, NM 87108, USA. E-mail: ytesfaig@lrri.org

Received: March 222015 | Accepted after revision: May 252015 | First published online: July 092015

Support statement: This work was supported by the State of New Mexico (appropriation from the Tobacco Settlement Fund), from the National Institutes of Health (P50HL107165 for B. Celli and Y. Tesfaigzi, RO1 HL068111 and ES015482 to Y. Tesfaigzi, R01CA164782 for Y. Tesfaigzi/S.A. Belinsky, R01 CA097356 for S.A. Belinsky, HL105339, HL114501, AI111475 for C.A. Owen, FAMRI CIA 123046 for C.A. Owen) and funds from GSK. Funding information for this article has been deposited with FundRef.

Conflict of interest: Disclosures can be found alongside the online version of this article at erj.ersjournals.com

\title{
References
}

$1 \quad$ Stripp BR, Reynolds SD, Boe IM, et al. Clara cell secretory protein deficiency alters Clara cell secretory apparatus and the protein composition of airway lining fluid. Am J Respir Cell Mol Biol 2002; 27: 170-178.

2 Long $\mathrm{XB}, \mathrm{Hu} \mathrm{S}$, Wang $\mathrm{N}$, et al. Clara cell $10-\mathrm{kDa}$ protein gene transfection inhibits NF-kappaB activity in airway epithelial cells. PloS One 2012; 7: e35960.

3 Bernard AM, Roels HA, Buchet JP, et al. Serum Clara cell protein: an indicator of bronchial cell dysfunction caused by tobacco smoking. Environ Res 1994; 66: 96-104

4 Chen J, Lam S, Pilon A, et al. The association between the anti-inflammatory protein CC10 and smoking status among participants in a chemoprevention trial. Cancer Epidemiol Biomarkers Prev 2007; 16: 577-583.

5 Laucho-Contreras ME, Polverino F, Gupta K, et al. Protective role for club cell secretory protein-16 (CC16) in the development of chronic obstructive pulmonary disease. Eur Respir J 2015; 45: 1544-1556.

6 Sood A, Petersen H, Blanchette CM, et al. Wood smoke exposure and gene promoter methylation are associated with increased risk for COPD in smokers. Am I Respir Crit Care Med 2010; 182: 1098-1104.

7 Hunninghake GM, Cho MH, Tesfaigzi Y, et al. MMP12, lung function, and COPD in high-risk populations. N Engl J Med 2009; 361: 2599-2608.

8 Vestbo J, Edwards LD, Scanlon PD, et al. Changes in forced expiratory volume in 1 second over time in COPD. N Engl J Med 2011; 365: 1184-1192.

9 Kim DK, Cho MH, Hersh CP, et al. Genome-wide association analysis of blood biomarkers in chronic obstructive pulmonary disease. Am J Respir Crit Care Med 2012; 186: 1238-1247.

10 Lomas DA, Silverman EK, Edwards LD, et al. Evaluation of serum CC-16 as a biomarker for COPD in the ECLIPSE cohort. Thorax 2008; 63: 1058-1063.

11 Guerra S, Vasquez MM, Spangenberg A, et al. Serum concentrations of club cell secretory protein (Clara) and cancer mortality in adults: a population-based, prospective cohort study. Lancet Respir Med 2013; 1: 779-785.

12 Broeckaert F, Clippe A, Wattiez R, et al. Lung hyperpermeability, Clara-cell secretory potein (CC16), and susceptibility to ozone of five inbred strains of mice. Inhal Toxicol 2003; 15: 1209-1230.

13 Dodge DE, Plopper CG, Rucker RB. Regulation of Clara cell $10 \mathrm{kD}$ protein secretion by pilocarpine: quantitative comparison of nonciliated cells in rat bronchi and bronchioles based on laser scanning confocal microscopy. Am J Respir Cell Mol Biol 1994; 10: 259-270.

14 Chen J, Lam S, Pilon A, et al. Higher levels of the anti-inflammatory protein CC10 are associated with improvement in bronchial dysplasia and sputum cytometric assessment in individuals at high risk for lung cancer. Clin Cancer Res 2008; 14: 1590-1597.

\section{Mefloquine as a potential drug against multidrug-resistant tuberculosis}

To the Editor:

In the article by ALSAAD et al. [1] in a recent issue of the European Respiratory Journal the authors reviewed six drugs with antimicrobial activity against Mycobacterium tuberculosis (phenothiazine, metronidazole, 
doxycycline, disulfiram, tigecycline and co-trimoxazole) which are not listed in the World Health Organization guidelines on multidrug-resistant tuberculosis (MDR-TB) treatment, but could be potential candidates for this use. Despite of the release of new drugs (delamanid, bedaquiline), treatment alternatives are still warranted, last but not least because of treatment costs. We would like to extend this list by evaluating the anti-malaria drug mefloquine.

Mefloquine is a synthetic quinine analogue. The anti-malarial effects of mefloquine are thought to be due to its accumulation within the food vacuole of the parasite where it interacts with haem [2]. Beyond its indisputable ability in malaria treatment and prophylaxis, mefloquine is bactericidal against Gram-positive bacteria and also has a poor activity against Gram-negative bacteria [3]. The minimal inhibitory concentration (MIC) of mefloquine for strains of staphylococci and enterococci was found to be $16 \mu \mathrm{g} \cdot \mathrm{mL}^{-1}$, and the minimal bactericidal concentrations ranged from 16 to $32 \mu \mathrm{g} \cdot \mathrm{mL}^{-1}$ [3].

GONÇALVES et al. [4] showed that mefloquine-oxazolidine derivates have in vitro activity against $M$. tuberculosis. In addition, mefloquine can inhibit the Mycobacteria species in a MIC range of $8-16 \mu \mathrm{g} \cdot \mathrm{mL}^{-1}$, as demonstrated by BERMUDEZ et al. [5] against Mycobacterium avium complex in vivo and in vitro.

We evaluated the in vitro activity of mefloquine against 21 MDR- and 92 non-MDR-TB strains detected in our centre between 2001 and 2013.

For this purpose we analysed the in vitro susceptibility test results of mefloquine assessed by MIC. Testing for MIC was performed on solid Middlebrook 7H10 agar plates as described elsewhere [6]. MICs were defined as the lowest drug concentration after twofold serially diluted concentration of mefloquine, that inhibits growth of $>99 \%$ of a bacterial proportion of the tested tuberculosis strain on solid Middlebrook $7 \mathrm{H} 10$ agar plates within $14-21$ days of incubation at $37^{\circ} \mathrm{C}$.

Among the $113 \mathrm{M}$. tuberculosis strains, 21 showed a resistance in vitro against isoniazid and rifampicin, which defines MDR-TB and the other 92 strains were "fully sensitive" against all first-line antituberculosis drugs.

We found the MICs for mefloquine in 17 (81\%) MDR-TB strains at $8 \mu \mathrm{g} \cdot \mathrm{mL}^{-1}$ and in four (19\%) MDR-TB strains at $4 \mu \mathrm{g} \cdot \mathrm{mL}^{-1}$. In $72(78.2 \%)$ of the "fully sensitive" tuberculosis strains, we detected a MIC for mefloquine at $8 \mu \mathrm{g} \cdot \mathrm{mL}^{-1}$, in $10(10.9 \%)$ fully sensitive tuberculosis strains at $4 \mu \mathrm{g} \cdot \mathrm{mL}^{-1}$ and in other $10(10.9 \%)$ tuberculosis strains at $16 \mu \mathrm{g} \cdot \mathrm{mL}^{-1}$ (table 1$)$.

Following oral administration of mefloquine, about $75-80 \%$ of the drug is absorbed, and time to peak concentration were found to be $7-24 \mathrm{~h}[7,8]$. There is little pre-systemic metabolism of the compound, which has a terminal elimination half-life of 14-41 days (medium 20 days) [7]. Mefloquine is quickly distributed throughout the body, and has a high affinity for lipids; in blood plasma it is essentially protein-bound. Mefloquine is metabolised mainly by the liver to produce carboxymefloquine, which has no anti-malarial activity and a toxicity and half-life similar to the parent molecule [9]. It is not known if the metabolite is active against M. tuberculosis, this needs to be explored in future studies.

It can be assumed that mefloquine is a drug with a very good tissue penetration. WERNSDORFER et al. [8] were able to show that 7 days after administration of $1250 \mathrm{mg}$ mefloquine, which is a standard therapeutic dose, the intracellular concentration in leukocytes was $>16 \mu \mathrm{g} \cdot \mathrm{mL}^{-1}$. Therefore, we can suspect that a regular weekly dose of mefloquine leads to intracellular concentrations $>16 \mu \mathrm{g} \cdot \mathrm{mL}^{-1}$ over 7 days. Besides favourable MICs, the administration of mefloquine once weekly could promote patients' compliance. Data about mefloquine concentrations in lung tissue are not available.

In conclusion, our data showed that mefloquine has good in vitro activity against M. tuberculosis and especially against MDR-TB strains.

But it must be mentioned that the incidence of side effects is high (47-90\%) and that higher doses of mefloquine are associated with even higher frequencies of adverse events [8]. Vertigo, nausea and

TABLE 1 Minimal inhibitory concentrations (MIC) of mefloquine against multidrug-resistant tuberculosis (MDR-TB) and non-MDR-TB-strains

\begin{tabular}{lcccr} 
& Patients $\mathbf{n}$ & \multicolumn{3}{c}{ MIC $\boldsymbol{\mu g} \cdot \mathbf{m L}^{-\mathbf{1}}$} \\
\cline { 3 - 5 } & & $\mathbf{4}$ & $\mathbf{8}$ & $\mathbf{1 6}$ \\
\hline MDR-TB & 21 & 4 & 17 & 10 \\
Non-MDR-TB & 92 & 10 & 72 & 10 \\
\hline
\end{tabular}


headache are the most frequently reported symptoms [10]. This may limit the potential drug's utility for some patients. For long-term treatment as it is desired for MDR-TB patients, the high intracellular concentration of mefloquine could allow the option to give the standard single dose of $1250 \mathrm{mg}$ every two or three weeks after an initial reduction of bacterial burden [8]. Whether such a treatment regimen is effective and able to reduce toxicity so that it would enable to tolerate mefloquine for 6 months and more has to be investigated in prospective studies including clinical effectiveness and pharmacokinetics. In general, we believe that treatment periods limited to 6 months for a single drug even within a long-term combined treatment of MDR-TB should be handled with caution, because no long-term data on the development of secondary resistance exist for the two drugs proposed for 6 months treatment period (delamanid, bedaquiline) [11].

Other studies have also shown that synergy between drugs can be of additional value $[3,5,12]$. The possible in vitro synergy between mefloquine and other tuberculosis drugs could be investigated by using either solid agar plates and/or fluid cultures [12].

Despite the frequent side effects, we suggest that the well-known drug should be evaluated in clinical studies on MDR- and non-MDR-TB patients for short-term efficiency, dose finding, long-term safety and long-term tolerability. clinical studies http://ow.ly/OYKEv

David Krieger ${ }^{1}$, Silvan Vesenbeckh ${ }^{1}$, Nicolas Schönfeld ${ }^{1}$, Gudrun Bettermann ${ }^{2}$, Torsten Thomas Bauer ${ }^{1,3}$, Holger Rüssmann ${ }^{2}$ and Harald Mauch ${ }^{2}$

${ }^{1}$ Klinik für Pneumologie, Lungenklinik Heckeshorn, HELIOS Klinikum Emil von Behring, Berlin, Germany. ${ }^{2}$ Institut für Mikrobiologie, Immunologie und Laboratoriumsmedizin, HELIOS Klinikum Emil von Behring, Berlin, Germany.

${ }^{3}$ Deutsches Zentralkomitee zur Bekämpfung der Tuberkulose (DZK), Berlin, Germany.

Correspondence: David Krieger, Klinik für Pneumologie, Lungenklinik Heckeshorn, HELIOS Klinikum Emil von Behring, Walterhoeferstr. 11, 14165 Berlin, Germany. E-mail: david.krieger@helios-kliniken.de

Received: Feb 252015 | Accepted after revision: June 042015 | First published online: July 232015

Conflict of interest: None declared.

\section{References}

1 Alsaad N, Wilffert B, van Altena R, et al. Potential antimicrobial agents for the treatment of multidrug-resistant tuberculosis. Eur Respir J 2014; 43: 884-897.

2 Palmer KJ, Holliday SM, Brogden RN. Mefloquine. A review of its antimalarial activity, pharmacokinetic properties and therapeutic efficacy. Drugs 1993; 45: 430-475.

3 Kunin CM, Ellis WY. Antimicrobial activities of mefloquine and a series of related compounds. Antimicrob Agents Chemother 2000; 44: 848-852.

4 Gonçalves R, Kaiser CR, Lourenço MC, et al. Mefloquine-oxazolidine derivatives, derived from mefloquine and arenecarbaldehydes: In vitro activity including against the multidrug-resistant tuberculosis strain T113. Bioorg Med Chem 2012; 20: 243-248.

5 Bermudez L, Kolonoski $\mathrm{P}, \mathrm{Wu}$ M, et al. Mefloquine is active in vitro and in vivo against Mycobacterium avium complex. Antimicrob Agents Chemother 1999; 43: 1870-1874.

6 Schönfeld N, Bergmann T, Vesenbeckh S, et al. Minimal inhibitory concentrations of first-line drugs of multidrug-resistant tuberculosis isolates. Lung India 2012; 29: 309-312.

7 Karbwang J, White NJ. Clinical pharmacokinetics of mefloquine. Clin Pharmacokinet 1990; 19: 264-279.

8 Wernsdorfer WH, Noedl H, Rendi-Wagner P, et al. Gender-specific distribution of mefloquine in the blood following the administration of therapeutic doses. Malar J 2013; 12: 443.

9 Wernsdorfer WH. Antimalarial drugs. Health Co-operation Papers 1997; 15: 151-198.

10 Rendi-WagnerP, Noedl $\mathrm{H}$, Wernsdorfer $\mathrm{WH}$, et al. Unexpected frequency, duration and spectrum of adverse events after therapeutic dose of mefloquine in healthy adults. Acta Trop 2002; 81: 167-173.

11 Olaru ID, von Groote-Bidlingmaier F, Heyckendorf J, et al. Novel drugs against tuberculosis: a clinician 's perspective. Eur Respir J 2015; 45: 1119-1131.

12 Bolhuis MS, van der Laan T, Kosterink JGW, et al. In vitro synergy between linezolid and clarithromycin against Mycobacterium tuberculosis. Eur Respir J 2014; 44: 808-811. 